\title{
Crime Victims and Offenders in Mediation: An Emerging Area of Criminology and Correctional Administration
}

\author{
Rangappa $\mathrm{N} \mathrm{M}^{1 *}$
}

\section{ABSTRACT}

Criminologists are playing an increasing role in all fields of life, the mediation of conflict between crime victims and their offenders. By serving as community organizers, program developers and managers, trainers and mediators, Criminologists are affecting criminal justice system. In correction, Criminology not only helps individuals, groups and community to solve problems, but also assists them to prevent offending behaviour and enrich their living. So, the main focus of the Criminology is upon helping people to prevent and control crime. The Criminology usually works with clients on a conscious level, helping them to face realities and solve problems in preventing and controlling offending behaviours. Victim-offender mediation provides an opportunity for crime victims to meet the offender, talk about the offence, express concerns and negotiate a mutually agreeable restitution agreement. A brief overview of mediation process is presented in this paper. The issues related to program development and replication is also identified.

Keywords: Crime, Mediation, Emerging Area, Criminology, Administration

Criminology emerged as profession in the $20^{\text {th }}$ century and today it is profession charged with fulfilling the social mandate of promoting well being and quality of life. Thus Criminology encompasses activities directed at improving human and social conditions and alleviating human distress and social problems. Criminologists are often vulnerable when faced with demands of accountability because of the strong tradition of private, intuitive ways of working and this assertion is particularly applicable to Criminologists in correctional services. Criminology emphasis a consistent and accurate intervention in the rehabilitation of the prisoners.

\section{The underlying assumptions of Criminology in the context of corrections are:}

(1) Criminology, like all other professions, has problem solving functions and hence, it can help offenders in their treatment and rehabilitation.

\footnotetext{
${ }^{1}$ Research Scholar, Department of Criminology and Forensic Science ,Karnataka University, Dharwad, India *Responding Author

(C) 2016 I M Rangappa; licensee IJIP. This is an Open Access Research distributed under the terms of the Creative Commons Attribution License (http://creativecommons.org/licenses/by/2.0), which permits unrestricted use, distribution, and reproduction in any Medium, provided the original work is properly cited.
} 


\section{Crime Victims and Offenders in Mediation: An Emerging Area of Criminology and Correctional Administration}

(2) Criminology practice is an art with a scientific and value foundation and, hence, correctional work is professional in nature.

(3) Criminology as a profession came into being and continued to develop because it meets human needs and aspirations recognized by society. Hence, it assumes some of the socialization and control functions of society and helps the offenders to reshape their behaviour.

(4) Criminology practice takes its values from those held by the society of which it is a part. However, its values are not necessarily or altogether those universally or predominantly held or practiced in society and hence, it emphasizes in treatment and rehabilitation of the offender.

(5) The scientific base of Criminology consists of three types of knowledge:

a. Tested knowledge,

b. Hypothetical knowledge that requires transformation into tested knowledge, and

c. Assumptive knowledge (or "Practice wisdom") that requires transformation into hypothetical and then into tested knowledge. The Correctional Criminology uses all these three types of knowledge, and carries a professional responsibility for knowing, at any time, which type of knowledge he is using and what degree of scientific certainty is attached to it.

(6) The knowledge needed for Criminology practice is determined by its goals and functions and the problems it seeks to solve and, hence, they are applicable in the administration of correction.

(7) The internalization of professional knowledge and values is a vital characteristic of the professional Criminology, since he is himself the instrument of professional help and he helps the offender to change his behaviour.

(8) Professional skill is expressed in the activities of the Criminology. It constitutes his artistic creation, resulting from three internal processes: first, conscious selection of knowledge pertinent to the professional task at hand in order to help the offender, second, fusion of this knowledge with Criminology and correctional values; and third, the expression of this synthesis in professionally relevant activity to administer correction and to modify offending behaviour.

These assumptions constitute commitments for the Criminology. It also means that the functions assigned to Criminology by society represent a two-fold responsibility. The first is to determine the professional activities through which it seeks to reach its socially approved goals and modify them as necessary in the light of changing social needs. The second is to exercise discipline and control over practice that would keep its professional accountability. A problem developed in the area of social interaction, whether raised as a problem by the individual or by a group in the community, calls for the professional services of the Criminology.

In correction, Criminology is an art because it requires great skills to understand delinquent and criminal behaviour. It is a science because of its problem-solving method and its attempt to be objective in determining delinquent and criminal activities and in developing principles and 


\section{Crime Victims and Offenders in Mediation: An Emerging Area of Criminology and Correctional Administration}

operational concepts to deal with delinquency and crime. It is a profession because it encompasses the attributes of a profession in dealing with offending behaviour.

The Criminology attempts to make it possible for the client to face and change his offending behaviour through this warm, accepting and understanding relationship. In Criminology, four fundamental activities can be distinguished: assessing the problem, planning for solution of the problem, implementing the plan and evaluating the outcome. Assessment of the problem, such as delinquency and criminal behaviour, requires various evaluative steps, logically consecutive, but in practice, synchronized. In the light of this assessment, a plan of action must be structured. Implementing the plan involves rendering all the specific and interrelated services appropriate to the given problem situation in the light of the assessment and planning. Finally, evaluation determines the effectiveness of service in the light of the expected outcome formulated as part of the planning activity. The interest among Criminologists and others in victim offender mediation has been growing during the past decade. In 1978, only a handful of mediation programs existed, primarily in the Midwest. These programs continue to be sponsored primarily by private social services agencies that work closely with courts. In this growing network, Criminologists are becoming active in many roles, including community organizers, program developers, board members, and staff or voluntary mediators.

The rich heritage of Criminology practice in the juvenile justice systems dates back to the turn of the century, when juvenile court was established. The concept of victim-offender mediation, however is largely absent from the Criminology literature. This article begins to build a bridge between Criminology practice in the emerging field and the Criminology literature. The article presents the purpose of this practice model and describes the mediation process. Finally, important issues related to program development and replications are presented.

\section{PURPOSE}

Victim-offender mediation programs provide a conflict resolution process that is meant to be fair to both the victim and the offender (Umbreit, 1985, 1988a). The mediator facilitates this process by allowing the parties first to address informational and emotional needs and then to discuss the victim's losses and to develop a mutually acceptable restitution plan (for example: repayment, working for the victim, working for the victim's choice of charity). Both crime victims and offenders are placed in a passive position by the criminal justice system, and often neither receives basic assistance or information. anger and frustration increase as the victim and offender move through the highly depersonalized justice process. Victims often feel powerless and vulnerable. Some even feel twice victimized, first by the offender and then by an uncaring criminal justice system that does not have time for them. Offenders rarely understand or confronted with the human dimension of their criminal behaviour-that victims are real people and not only object to the abused. Offenders have many rationalizations for their actions against 


\section{Crime Victims and Offenders in Mediation: An Emerging Area of Criminology and Correctional Administration}

others The victim-offender mediation process draws on old -fashioned principles that recognize that crime is fundamentally against people, and not only against the state. Instead of placing the victim in a passive role and reinforcing an adversarial dynamic that often results in little emotional closure for the victim and little, if any, direct accountability by the offender to the victim, the mediation process actively facilitates personal conflict resolution.

\section{Mediation process}

There are four phases in the victim-offender mediation process (Umbreit, 1988a): intake, preparation for mediation, mediation, and follow-up.

\section{Intake Phase:}

The intake phase begins with the court referral of the offender (most often convicted of theft or burglary). Most programs accept referrals after a formal admission of guilt has been entered with the court. Some programs accept cases that are referred before formal admission of guilt as part of a deferred prosecution effort. The case is assigned to the mediator.

\section{Preparation Phase:}

The Preparation Phase begins when the mediator meets separately with the offender and victim. During the individual sessions, the mediator listens to the story of the each party, explains the program, and encourages each party's participation. Mediators usually meet first with the offender and, if he/she is willing to proceed with mediation, later with the victim. Encouragement of victim and offender participation in the mediation process must not be confused with coercion. The process is meant to empower victims and offenders by presenting them with choices.

\section{Mediation Phase:}

Following the separate meetings and if both parties choose to participate, the mediator schedules a joint meeting. The mediation session begins with the media for explaining his or her role, identifying the agenda, and stating communication ground rules. The first part of the meeting is a discussion of the facts and feelings related to the crime. Victims are given the rare opportunity to express their feelings directly to the person who committed a crime. They can get answers to question such as "why me?" "How did you get into our house?".Were you stalking us and planning to come back?” Victims are often relieved to finally see the offender, who usually bears little resemblance to the frightening character they had envisioned.

The mediation session places offenders in the uncomfortable position of facing the person against whom they committed the crime. They are given the equally rare opportunity to display a more human dimension to their character, even to express remorse personally. Through discussion of their feelings, both victim and offender can deal with each other as people, often 


\section{Crime Victims and Offenders in Mediation: An Emerging Area of Criminology and Correctional Administration}

from the same neighbourhood, rather than as stereotypes and objects. When the sharing of facts and feelings related to the crime is concluded, the second part of the meeting is directed to discussion of losses and negotiation of a mutually acceptable restitution agreement as a tangible symbol of conflict resolution and a focus point for accountability. Mediators do not impose a restitution settlement. Joint victim-offender meetings usually last about one hour, with some meetings lasting two hour.

\section{Follow -Up Phase:}

The follow-up phase begins when the referral agency approves the restitution agreement and ends with the closure of the case. Tasks to be completed during this phase include making monthly telephone calls to the victim to monitor fulfillment of the restitution agreement; if necessary, contacting the probation officer to secure compliance by the offender; if necessary, scheduling a joint meeting with the victim and the offender; and completing the final paperwork to close the case.

\section{DEVELOPMENT AND REPLICATION ISSUES:}

As a growing number of communities consider developing a victim-offender mediation program, a number of important issues should be considered. Building public and system support for the new program is crucial. Experience in many communities has indicated that although some criminal justice officials may be initially skeptical (most notably prosecutors, judges, and victim's advocates), their support usually can be obtained. Once they learn more about the mediation process and how it affects both victims and offenders, officials usually become supportive, or even active, in developing the new program. The most likely referral sources are judges and probation staff. Prosecutors, counselors, and victims' assistance staff can also be effective sources.

Identifying an appropriate group of victims and offenders to work which is vital experience in hundreds of mediation cases over the past years has shown that the program is effective with non violent property offences such as vandalism, theft, and burglary. Most offenders are either first or second time law violators. Unlike other types of mediation, most (but not all) victims and offenders have no prior relationship. Many mediation programs can also work with assault cases. A few programs are beginning to work with more violent crimes such as armed robbery, sexual assault, and attempted homicide. In fact, victims of violent crime have often been among those who advocate extending the mediation process to more serious cases. However, this does not include domestic assault. The mediation process has been effective in assisting victims of violent crime in regaining a sense of power and control in their lives, as well as the ability to "let go" of the victimization experience (Umbreit, 1988b). However, mediation for violent crimes requires a more intense process and is not recommended for new programs. 


\section{Crime Victims and Offenders in Mediation: An Emerging Area of Criminology and Correctional Administration}

Those interested in being mediators need to decide early whether to work with juvenile or adult offenders. Because the juveniles and adult offenders are different, working with both requires more initial development time. Working collaboratively with existing victims' service programs and offender treatment programs is important. Although the victim-offender mediation process offers a number of benefits to both parties, the process also has limitations. Many victims and offenders need more extensive services than can be offered through the mediation process. At best, the mediation process is part of a larger response to the needs facing crime victims and their offenders. Securing resources to operate a new victim-offender mediation program are critical. In most communities, a small staff that supervises a larger pool of trained volunteer mediators is sufficient. This keeps the program's costs down and, more importantly, empowers citizens to become directly involved in resolving criminal conflict in their communities. The provision of twenty five to thirty hours of effective mediation training and continued in service training is important.

Replication of the victim-offender mediation model requires effective community organizing and program development skills. Most importantly, it requires a deep commitment to restorative principles of justice that empower crime victims and their offenders to resolve their conflict and to let go of the victimization experience.

\section{CONCLUSION}

It is clear that community corrections have gone through a long and complicated process of development. Throughout this process, the specific purpose of community corrections has not always been clear. Indeed, many recognized experts, authors, and researchers offer competing views on the purpose of community corrections, resulting in a great deal of confusion and uncertainty related to the effectiveness of community-based sanctions. These developments help to make sense of the various challenges associated with community corrections sanctions and also provide guidance for future uses of these sanctions. Lastly, it is clear that there is a great deal of variety from state to state in regard to the community supervision process. The implementation of probation and parole comes in many shapes, forms, and methods, creating a rich yet challenging process of offender supervision in communities throughout India. The work with delinquents and criminals is often seen as effective techniques for modifying attitudes and behaviour. Criminology has an important role to play in the control correction and prevention of delinquency and crime. Criminology attempts to help the individual, their family and the community to face and solve delinquency and crime through the utilization of individual, family and community resources. Therefore, professional Criminology in correctional settings is a comprehensive constructive social attitude, therapeutic in some instances, restraining in some instances, but preventive in its total social impact. 


\section{Crime Victims and Offenders in Mediation: An Emerging Area of Criminology and Correctional Administration}

\section{Acknowledgments}

The author appreciates all those who participated in the study and helped to facilitate the research process.

\section{Conflict of Interests}

The author declared no conflict of interests.

\section{REFERENCES}

Coates, R.B., \& Gehm, J. (1989), An empirical Assessment. In M.Weight \& B.Galaway (Eds.), Mediation and Criminal Justice. Sage Publication, London.

Davis, R, Tichane, M., \& Grayson, D. (1980), Mediation and arbitration as alternatives to prosecution in felony arrest cases: An evaluation of the Brooklyn Dispute Resolution centre, New York: Vera Institute of Justice.

Desai, Armaity S. (1978), Review of Criminology Education in India, Retrospect and Prospect, Report of the Second Review Committee, University Grants Commission, New Delhi

Devsia V V 'Criminologistsin correctional settings’, Indian Social Institute, New Delhi.

Marshall T \& Merry.S (1990), Crime and accountability: Victim offender mediation. Nashville, TN: Abingdon Press.

Umbreit M S (1985), 'Crime and reconciliation: Creative options for victims and offenders'. Nashville, TN: Abingdon Press.

Umbreit M S (1993), Crime Victims and offenders in Mediation: An emerging area of Criminology practice'. Criminology. Vol.38, No 3, May 1993. National Association of Criminologists Press. Pp: 69-73.

Wright M \& Galaway B (Eds), (1988), Mediation and Criminal Justice, Sage Publication, London.

Yelaya, Shankar A. (1979), "Some Recent Studies on Criminology Practice: Implications for Criminology Education,” Indian Journal of Criminology, XL, 2, July, Pp: 153.

How to cite this article: M Rangappa (2016), Crime Victims and Offenders in Mediation: An Emerging Area of Criminology and Correctional Administration, International Journal of Indian Psychology, Volume 3, Issue 4, No. 58, ISSN 2348-5396 (e), ISSN: 2349-3429 (p), DIP: 18.01.049/20160304, ISBN: 978-1-365-24976-1 